\title{
Uwagi o dramaturgii filmu dokumentalnego
}

W historii polskiego filmu dokumentalnego przez lata dominował film krótkometrażowy. Do jego zasadniczych cech należała skłonność do ujęć metaforycznych, do syntezy i skrótu, do wyrazistej puenty. Te elementy wyróżniały polski film dokumentalny na tle produkcji europejskich i światowych. W ostatnich latach polscy dokumentaliści realizują jednak coraz więcej filmów średnio - i pełnometrażowych. Polskie kino niefikcjonalne zmienia się pod wpływem wymagań rynku, nowych kanałów dystrybucji i odmiennych od dotychczasowych oczekiwań widzów. Filmowcy stają przed nowymi problemami związanymi z konstrukcją dłuższych form dokumentalnych. Zasadniczym wyzwaniem staje się z pewnością dramaturgia[1].

Linia dramaturgiczna, dramaturgiczne napięcie, punkty kulminacyjne, progresja napięć to terminy, które stosujemy zwykle w procesie analizy filmu fabularnego. Tymczasem mają one oczywiście zastosowanie również $\mathrm{w}$ refleksji nad dokumentem, a szczególnie dokumentem pełnometrażowym. Choć kino fikcji wciąż odróżnia od kina niefikcjonalnego odmienny status świata przedstawionego, to wiele elementów konwencji uchodzących dotąd za dystynktywne uległo zatarciu. Granica pomiędzy podstawowymi rodzajami filmowymi staje się coraz mniej wyraźna. W szerokim pasie pogranicza znajdują się nie tylko coraz bardziej popularne mockumenty, lecz także dłuższe formy dokumentalne, które korzystają z rozwiązań dramaturgicznych typowych dla filmu fabularnego. Sprawiają one coraz większy kłopot krytykom i filmoznawcom, a jednocześnie cieszą się wśród widzów coraz większą popularnością.

Czy reguły dramaturgiczne w pełnometrażowym dokumencie są takie same jak w kinie fabularnym? Czy w obu rodzajach mogą obowiązywać identyczne chwyty, których celem jest zdobycie zainteresowania widza i utrzymanie odbiorcy przed ekranem? Film do-

[1] Nie wszyscy filmowcy i filmoznawcy podzielają pogląd o odmienności reguł dramaturgicznych rządzących filmem krótkometrażowym i pełnometrażowym. Badania Williama Guynna nad związkami pomiędzy filmem fabularnym a dokumentalnym pokazują, że niezależnie od metrażu dokumentu w każdym są widoczne tak samo silne związki ze strukturami fabularnymi. O badaniach Guynna i kontrowersjach metodologicznych wokół nich zob. szerzej M. Przylipiak, Poetyka filmu dokumentalnego, Gdańsk-Słupsk 2004, s. 74-75. Pogląd o powszechności zastosowania reguł kina fikcjonalnego w filmie dokumentalnym podziela również BrianWinston. Idem, Claiming the Real, London 1995. Lew Hunter jest zdania, że nie ma między nimi zasadniczej różnicy. Obowiązują w nich te same reguły opowiadania. Idem, Kurs pisania scenariuszy, przeł. T. Szafrański, Myślenice 2013, s. 122. 
kumentalny, podobnie jak fabularny, jest opowiadaniem. Ric Burns, amerykański dokumentalista, w rozmowie z Sheilą Curran Bernard stwierdził:

Cegiełkami, z których budujesz film, są sceny, które mają początki, środki i końce, mają swoje wewnętrzne rytmy i punkty szczytowe. [...] Film jest w zasadzie jak muzyka, jak każda forma sztuki oparta na linii czasu. Chodzi o efekt progresywnego przyrostu wynikającego z rozwoju zdarzeń. Czy potrzebny jest mocny akcent? Czy strumień nie stanie się zbyt męczący, jeśli nie nastąpi pauza? Czy nie powinienem otrzymać informacji, którą otrzymałem w ostatniej scenie, w nieco bardziej umiarkowanym tempie, a może należało je zwiększyć? Wydaje mi się, że to, o co należy dbać szczególnie, to wektor klarowności i wektor emocji. Dlatego, że są ze sobą ściśle związane. Im klarowniej przedstawione wydarzenie, tym silniejsze oddziaływanie emocjonalne[2].

Oba rodzaje odróżnia natomiast z pewnością stosunek do rzeczywistości. W moim przekonaniu fakty te w sposób znaczący wpływają na dramaturgię filmu dokumentalnego.

Film otwarty i zamknięty na rzeczywistość w refleksji teoretycznej Marcela Łozińskiego
Punktem wyjścia moich rozważań nad dramaturgią współczesnego dokumentu chciałabym uczynić pracę dyplomową Marcela Łozińskiego Scenariusz a realizacja $w$ filmie dokumentalnym. Mimo że upłynęło ponad czterdzieści lat od chwili jej powstania, wiele uwag poczynionych wówczas przez jej autora nie straciło na aktualności. Na pierwszych stronach swej dysertacji dyplomowej Łoziński cytuje Federico Felliniego: „Realizować film - to znaczy znaleźć moment równowagi między własną ideą a sugestiami rzeczywistości”[3]. Uwaga twórcy Osiem i pół dotyczyła wprawdzie filmu fabularnego, ale znajduje zastosowanie również w dokumencie. Łoziński wyróżnia trzy zasadnicze jego typy: dokument otwarty, zamknięty i półotwarty. Dwa pierwsze stanowią pewne ekstrema na kontinuum, które opisuje stosunek reżysera-dokumentalisty do filmowanej rzeczywistości. Jak pisze Łoziński, „dokumentalista może być rzetelnym świadkiem opisywanego świata” lub „konstruktorem zupełnie nowej rzeczywistości filmowej”[4]. W pierwszym przypadku „wiedza reżysera powiększa się w czasie realizacji, pozostaje on podporządkowany swojej materii filmowej i jej dramaturgii”; w drugim - „rzeczywistość jest dla realizatora jedynie «cegiełką», z której buduje on swój własny, kreowany świat”[5]. W tego typu filmach „rzeczywistość nie może przynieść większych niespodzianek, ponieważ nie ma ona w takim filmie na ogół żadnego przebiegu, a jej wycinki podporządkowane zostają uprzednio zaplanowanej strukturze" [6]. Formuła pośrednia, którą Łoziński określa jako film półotwarty, polega
[2] Cyt. za: S.C. Bernard, Film dokumentalny. Kreatywne opowiadanie, przeł. M. Bukojemski, Warszawa 2011, s. 364.

[3] Cyt. za: M. Łoziński, Scenariusz a realizacja $w$ filmie dokumentalnym, praca dyplomowa napisana na Wydziale Reżyserii PWSFTviT w Łodzi w roku
1973, dostępna w Bibliotece PWSFTviT w Łodzi, sygn.

D1046, s. 1.

[4] Ibidem, s. 2.

[5] Ibidem, s. 3 .

[6] Ibidem, s. 23. 
na „analitycznej obserwacji rzeczywistości przetworzonej, zagęszczonej, traktowanej później, w czasie realizacji, jako rzeczywistość istniejąca"[7]. Dla twórcy stworzona przez niego rzeczywistość stanowi punkt wyjścia do poszukiwania dramaturgii w niej samej, a nie na stole montażowym. Zwykle zakłada ingerencję w nią już na poziomie scenariusza. Autor Happy endu jednoznacznie opowiada się po stronie metod dokumentalnych otwartych na rzeczywistość, nawet jeśli początkowo jest ona poddana silnej ingerencji. Już w chwili pisania pracy dyplomowej był jednak w pełni świadomy, że „rzeczywistość nie myśli - musi to za nią zrobić autor”[8]. Teoretyczne założenia direct cinema uważał więc za artystycznie jałowe. W swych późniejszych filmach chętnie posługiwał się ,inscenizacją psychodramatyczną”, czyli prowokowaniem sytuacji, „w których mielibyśmy jakąś szansę na dokumentalne wyłapanie cząstek prawdy o bohaterze"[ ${ }^{9}$. Dokumentalista musi znaleźć formę dla rzeczywistości i w tej formie się wyrazić.

W twórczości Marcela Łozińskiego dominują filmy półotwarte, które cechuje różny stopień ingerencji w rzeczywistość prefilmową. Są wśród nich również dokumentalne utwory pełnometrażowe, których status genologiczny nie był dla ówczesnej krytyki oczywisty, jak zrealizowany w roku 1977 dokument Jak $\dot{z} y c ́$ czy nakręcony niemal trzydzieści lat później film Jak to się robi (2006). W Jak żyć Łoziński ukazuje sytuację modelową: odbywa się letni obóz ZSMP dla młodych małżeństw. Rada Obozu ogłasza konkurs na wzorcową rodzinę. Jedno z małżeństw nie chce jednak brać w nim udziału, nie zamierza podporządkować się regułom gry. „Jak zobaczymy, jest to film o totalitarnym porządku społecznym i stosunku jednostek do niego. Taką wymowę osiągnął Łoziński, wkraczając w materię filmowanej rzeczywistości $z$ dużym repertuarem zabiegów inscenizacyjnych"[10]. Reżyser wprowadził w filmowaną rzeczywistość kilka centralnych postaci, przede wszystkim przewodniczącego Rady Obozu Edwarda Zymana oraz małżeństwo Rozhinów. Wymyślił konkurs, poszczególne konkurencje i główną nagrodę.

Wprowadzenie elementów inscenizacji nie zmienia znaczeń filmu, ale przyspiesza ich pojawienie się, kumuluje i wyjaskrawia. [...] Dzięki wprowadzeniu na plan tak wielu zabiegów inscenizacyjnych Łoziński zbliżył Jak żyć do modelu filmu fabularnego. [...] Dzieło Łozińskiego to film dokumentalny, $\mathrm{z}$ dużą liczbą zabiegów inscenizacyjnych. Ale tych w nadmiarze nie pozbawiony był także Nanook Flaherty'ego. Jak żyć pozostaje dokumentem autorytatywnego porządku społecznego i mentalności społecznej Polski i Polaków połowy lat 70[11].

Zbliżoną formułę dokumentalną Łoziński zastosował w drugim ze wspomnianych filmów. By pokazać mechanizm „tworzenia” politycznego działacza oraz populizm dzisiejszej polityki, sfilmował

[7] Ibidem, s. 4.

[8] Ibidem, s. 6.

[9] Ibidem, s. 18.

[10] K. Kornacki, Polityka, psychologia i człowiek - twórczość Marcela Łozińskiego, „Kwartalnik Filmowy” 1998, nr 23, s. 166.

[11] Ibidem, s. 190. 
postępowanie Piotra Tymochowicza, jednego z najbardziej znanych w Polsce twórców wizerunku. W tym przypadku jednak w rzeczywistość ingerował przede wszystkim bohater, który inicjował zdarzenia na potrzeby filmu.

Od sensacji do propagandy zamykanie dramaturgicznej struktury
Gdyby oczyścić refleksje Łozińskiego zawarte w pracy Scenariusz a realizacja $w$ filmie dokumentalnym $\mathrm{z}$ uwag wartościujących, które $\mathrm{w}$ rozprawie pisanej przez aktywnego twórcę nie są niczym zaskakującym, oraz z refleksji etycznej, której centrum stanowią rozważania o uczciwości dokumentalisty, można by odnieść ustalenia autora do zagadnienia współczesnej dramaturgii. Dwóm podstawowym typom wskazanym przez twórcę Jak żyć - filmowi otwartemu i zamkniętemu - odpowiadają dwa zasadnicze wzorce dramaturgiczne kina dokumentalnego. Warto zaznaczyć, że oba stanowią modele abstrakcyjne, które nie są nigdy realizowane w czystej postaci. W przypadku drugiego porządek dramaturgiczny zostaje ustanowiony jeszcze przed zdjęciami, w trakcie dokumentacji lub po niej. W ostatnich latach coraz częściej stosowane są rozwiązania charakterystyczne dla kina gatunków. Szczególnie przydatny okazuje się w tym wypadku schemat śledztwa - poszukiwania bohatera, sprawcy przestępstwa lub zbrodni. Przykładem twórcy, który korzystał z tej formuły od końca lat 8o., jest jeden z najbardziej znanych amerykańskich dokumentalistów Errol Morris. W roku 1988 zrealizował film Cienka niebieska linia, w którym opowiadał historię mężczyzny skazanego na śmierć za zabójstwo policjanta. Kolejni świadkowie odkrywają fragmenty prawdy o zdarzeniach feralnej nocy. Nie układają się one w spójną całość. Obraz zdarzeń podlega nieustannej weryfikacji. Wizualnym ekwiwalentem tego procesu stają się powracające na zasadzie lejtmotywu, inspirowane stylistyką filmów noir, ujęcia inscenizowane, które ukazują moment zbrodni, choć ani sposób kadrowania, ani mrok nocy nie pozwalają dostrzec, kto wyciągnął broń i strzelił. Zainscenizowane zostały również ujęcia przedstawiające długie przesłuchanie podejrzanego. „Widz jest wprowadzany stopniowo w świat kryminału, ale reżyser wymaga od niego aktywnego udziału i poddania się nastrojowi grozy w celu wyciągnięcia właściwych wniosków" [12]. Dramaturgia filmu opiera się ponadto na nawrotach, które nadają Cienkiej niebieskiej linii niemal transowy, pulsujący rytm, wydobywany dodatkowo przez charakter muzyki Philipa Glassa. Podążamy tropem kolejnych podrzucanych przez bohaterów śladów i pomysłów ich interpretacji. Niektóre zbliżają nas do prawdy o zdarzeniu, inne od niej oddalają. Obiektywny obraz faktów nie istnieje, a jednak sąd musiał podjąć decyzję, oprzeć się na najbardziej wiarygodnych przesłankach. Napięcie stopniowo narasta. Jego rozładowanie następuje dopiero w finale, gdy usłyszymy magnetofonowe nagranie skazanego. Struktura oparta na repetycjach
[12] A. Sadowska, Outsiderzy, geniusze i wielka polityka. Bohaterowie i styl dokumentów Errola Morrisa, w:
Metody dokumentalne w filmie, red. D. Rode, M. Pieńkowski, Łódź 2013, s. 253. 
i retardacjach pozostawia jednak niepokój, przekonanie, że dotknęliśmy tylko cząstki prawdy, poznanie jej w sposób zobiektywizowany nie jest możliwe. Zacieranie granicy pomiędzy przekazem niefikcjonalnym i fikcjonalnym ma w filmie Morrisa konsekwencje również znaczeniowe, koresponduje bowiem z próbą ukazania nieoczywistej, niejasnej granicy pomiędzy iluzją a prawdą oraz z przekonaniem o zawodności naszych zmysłów. Film Morrisa bywa niekiedy kwalifikowany jako fabularyzowany dokument, o czym z pewnością decyduje znaczna liczba ujęć inscenizowanych i stylizowanych. O dramaturgii Cienkiej niebieskiej linii decydują jednak nie nawiązania do kina gatunków obecne w poszczególnych scenach, lecz zabieg nałożenia na zdokumentowaną rzeczywistość struktury charakterystycznej dla kina fabularnego.

Za sprawą współczesnych dokumentalistów konstrukcja dramaturgiczna zaczerpnięta z kryminału okazuje się atrakcyjną formułą opowiadania rozmaitych historii. W Sugar Manie (2012) Malik Bendjelloul odkrywa stopniowo nieznanego wcześniej muzyka Sixto Rodrigueza. Widz dopiero w finale filmu będzie mógł go zobaczyć. Na oczekiwaniu budowane jest również napięcie w filmie Johna Maloofa i Charliego Siskela Szukając Vivian Maier (2013). Autorzy, podążając tropem miłośnika fotografii i odkrywcy dzieł anonimowej fotografki, stopniowo odkrywają jej tożsamość, zbierają ślady i okruchy wspomnień. Wyłania się z nich obraz podwójny: trudnej lokatorki i niefrasobliwej niani oraz subtelnej i wrażliwej artystki. W Polsce z tej formuły kina skorzystał Bartosz Paduch, realizując Totart, czyli odzyskiwanie rozumu (2014). Opowiada o artystach alternatywnych, prowokatorach działających w latach 8o. w ramach kontrkulturowej grupy z Gdańska, której niekwestionowanym liderem był Zbigniew Sajnóg. Na film składają się materiały archiwalne ukazujące fragmenty performancéów przygotowywanych przez Totartowców oraz zarejestrowane współcześnie wywiady z byłymi członkami grupy. Wracają oni do miejsc, w których niegdyś działali, wspominają, ale wnoszą również w film o przeszłości informacje o sobie dziś, o tym, kim stali się po latach. Są wśród nich Tymon Tymański, Paweł Konjo Konnak, Dariusz Brzóskiewicz, Paweł Mazur. Niektórzy tworzą nadal w ramach sceny alternatywnej, inni zrobili karierę komercyjną, pozostali wycofali się z życia artystycznego zupełnie. Największą tajemnicą pozostaje los lidera Totartu. Odsłanianie kolejnych epizodów z jego życia, jego artystycznych i życiowych wyborów, staje się dramaturgiczną osią filmu. Aż do finału bohater pojawia się jednak wyłącznie w archiwaliach i w cudzych relacjach. Paduchowi udaje się nawet wzbudzić wątpliwości, czy Sajnóg nadal żyje. Sekwencję sugerującą jego śmierć możemy uznać za moment kulminacyjny filmu. $Z$ ogromnym zaskoczeniem widz przyjmuje więc zwrot w finale, kiedy bohater pojawia się na ekranie. Pewna przewrotność tego typu realizacji polega na opowiadaniu o bohaterze bez bohatera, o nim pod jego nieobecność.

„Zamknięcie” dokumentu tego typu może zostać wzmocnione za pomocą prowadzonej równolegle linii argumentacyjnej, której 
funkcją podstawową jest udowodnienie założonej przez reżysera tezy. W tego typu filmach struktura dyskursywna dominuje nad fabularną, niejako ją przesłania. Przykładem takiej realizacji jest debiutancki film Michaela Moore’a Roger i ja (1989). Moore, co stanie się znakiem rozpoznawczym kolejnych jego filmów, pierwszoplanowym bohaterem czyni jednak przede wszystkim samego siebie. Tytułowy Roger to Roger Smith, prezes General Motors. Moore podąża jego śladem, próbuje umówić się na spotkanie z nim, podstępem wedrzeć się do siedziby GM. Jako samozwańczy wysłannik społeczności miasta Flynt pragnie przedstawić swe zarzuty dotyczące przede wszystkim likwidowania przez koncern fabryki, co prowadzi do zubożenia i degrengolady miasta. Za moment kulminacyjny obu porządków - argumentacyjnego i dramaturgicznego („śledczego”) - można uznać sekwencję montowanych równolegle scen, które ukazują bezrobotnych wyrzucanych ze swych domów na bruk i uroczystości bożonarodzeniowe w głównej siedzibie GM w Detroit. Przez większą część filmu Roger Smith pojawia się jedynie w deprecjonowanych przez autora materiałach telewizyjnych. Dopiero w końcowej części Roger i ja widzimy Smitha przemawiającego, co „tu i teraz” rejestruje kamera Moore'a. Charakter manipulacji archiwaliami i prowokacji[13], które stosuje Moore, prowadzi do ostatecznego zdominowania fabularnej struktury, wydarzeń połączonych ze sobą ciągłością czasoprzestrzenną i przyczynowo-skutkową, przez porządek argumentów, mniej lub bardziej przekonujących, na rzecz tezy o bezwzględnym działaniu współczesnych korporacji.

Jeszcze bliżej modelu zamkniętego znajdują się popularne dziś filmy found footage, w tym wiele dokumentów historycznych, które obficie korzystają z archiwaliów. Natomiast za skrajny przypadek „zamknięcia" można uznać kino propagandowe. W tego typu filmach bardzo często narracja zostaje całkowicie wchłonięta przez element dyskursywny. Film przestaje być wówczas wyłącznie opowiadaniem, a staje się serią obrazów, których funkcją podstawową jest zilustrowanie tezy. Najjaskrawszych przykładów takiej propagandy dostarcza kino III Rzeszy (np. filmy dokumentalne związane z akcją $\mathrm{T} 4$ ) i filmy socrealistyczne. Wydaje się, że dominacja linii argumentacyjnej prowadzi w konsekwencji do użycia dramaturgii jako wehikułu treści zideologizowanych, wizji świata ściśle określonej i nie podlegającej dyskusji.

Otwieranie się na dramaturgię rzeczywistości
Drugi biegun dokumentalnej dramaturgii reprezentują filmy otwarte na rzeczywistość, choć niepozbawione formy. Niemal już klasycznym przykładem są realizacje direct cinema [14]. Choć twórcy nurtu zakładali minimalny zakres ingerencji w filmowaną rzeczywistość, to
[13] Więcej na ten temat: K. Klejsa, Populizm w multipleksie. Polityka i estetyka filmów Michaela Moore’a, w: Metody dokumentalne..., op. cit., s. 269 i n.

[14] Łoziński odnosił się do dokonań nurtu niezwykle krytycznie: „Cinema direct obrodzi dzisiaj w postaci tendencji «antyscenariuszowej», hołdującej na- iwnemu wyobrażeniu, że sama rzeczywistość zbuduje film, że autor może się za nią ukryć. Większość takich filmów odznacza się niewiarygodnym niechlujstwem warsztatowym [...], na ogół nijaką, prymitywną realizacją i ogromną monotonią tematyczną". M. Łoziński, op. cit., s. 6 . 
warto pamiętać, że właściwie żaden z nakręconych przez nich filmów nie realizuje poetyki deklarowanej. Jak zauważa monografista kina bezpośredniego Mirosław Przylipiak, „to, co uchodzi za powszechnie funkcjonujący w historii kina opis dokonań kina bezpośredniego, w istocie rzeczy jest zapisem chęci, deklaracji, zamierzeń, poglądów, a nie samych filmów" [15]. Warto odnotować, że twórcy direct cinema chętnie sięgali po tematy, w których drzemała „naturalna”, niewymuszona dramaturgia, np. zawody sportowe, trasy koncertowe, pojedyncze koncerty. Dramaturgia tych zdarzeń stawała się źródłem dramaturgicznego porządku filmu. To, co wyróżniało tych twórców, to otwarcie na przypadek, który niekiedy decydował o ostatecznym przebiegu opowiadanej historii. W filmie Gimme Shelter bracia Maysles ukazują ostatnie występy z amerykańskiej trasy koncertowej The Rolling Stones w roku 1969. Na pierwszą część filmu składają się relacje z koncertów w Madison Square Garden, nagranie Wild Horses w Muscle Shoals Sound Studio w Alabamie, jednocześnie śledzimy przygotowania do finałowego, darmowego występu zespołu. Zasadniczą część filmu stanowi zapis tego właśnie koncertu, który po długich negocjacjach odbył się w Altamont. Zewsząd nadciągają tysiące fanów, organizatorzy nie są przygotowani na taką liczbę widzów, brakuje należytej ochrony. Podnieceniu związanemu ze zbliżaniem się koncertu towarzyszy napięcie wynikające z zachowań widzów i organizatorów. Momentem kulminacyjnym sekwencji zrealizowanej w Altamont oraz całego filmu jest scena zabójstwa, którego dopuszcza się jeden $\mathrm{z}$ agresywnych ochroniarzy z Hells Angels na grożącym mu bronią widzu. Eskalacja przemocy, narastanie niepokoju jest budowane na podstawie pierwszej informacji z radia o ofiarach śmiertelnych, którą widz otrzymuje już na samym początku filmu. Porządek dramaturgiczny wyrasta $\mathrm{w}$ dużej mierze z porządku zdarzeń rzeczywistości, które zostały na stole montażowym poddane kondensacji, ale umieszczenie historii feralnego koncertu w ramie narracyjnej, którą stanowią ujęcia zespołu w montażowni, nadaje jej dodatkowe znaczenia. Dzięki nim zostaje wprowadzony do filmu wątek autotematyczny:

Czy refleksywność tego filmu ujawnia odpowiedzialność muzyków, czy ją maskuje, nie jest, w moim odczuciu, najważniejsze. Odgrywa ona bowiem daleko ważniejszą rolę, inspirując do rozważań nad odpowiedzialnością mediów za obrazy kultury, a także odpowiedzialnością filmowców spod znaku kina bezpośredniego[16].

W tradycji polskiego kina idea poszukiwania dramaturgicznego porządku w rzeczywistości najsilniej uobecniła się w twórczości i teoretycznej refleksji Krzysztofa Kieślowskiego. W swej pracy dyplomowej pisał:

Wspaniała, bogata, nieogarnięta rzeczywistość, gdzie nic się nie powtarza, gdzie nie można robić dubli. O jej rozwój nie musimy się martwić, dostarczy

[15] M. Przylipiak, Kino bezpośrednie 1960-1963, Gdańsk 2007, s. 30.

[16] M. Przylipiak, Kino bezpośrednie 1963-197o.
Czas autorów, Gdańsk 2014, s. 16o. W książce została zamieszczona obszerna analiza wspomnianego filmu. Ibidem, s. 150-16o. 
nam codziennie nowych, niezwykłych ujęć. Właśnie rzeczywistość - i to nie jest paradoks - jest wyjściem dla dokumentu. Trzeba tylko uwierzyć jej do końca, w jej dramaturgię - w dramaturgię rzeczywistości. [...] Element akcji, niespodzianki, pointy - tak istotny w dramaturgii klasycznej, element zawieszenia, nierozwiązania, nieuporządkowanych wątków - tak istotny w dramaturgii współczesnej - to wszystko nie jest wymyślone, to przecież naśladowanie (różnie widzianej) rzeczywistości. Chodzi o to, żeby przestać ją naśladować, udawać, żeby brać ją taką, jaka jest. Właśnie z jej brakiem point, z jej porząadkiem i bałaganem jednocześnie - to najnowocześniejsza i najprawdziwsza ze struktur[17].

Jedynym filmem, w którym wedle jego własnej opinii udało mu się zrealizować wyłożoną w pracy ideę, był dokument Pierwsza miłość (1974). Co warto zaznaczyć, jest to film 54-minutowy, a więc średniometrażowy. Kieślowski opowiada o roku z życia dwojga młodych ludzi, uczniów jeszcze, którzy stają przed trudnymi wyborami i koniecznością wzięcia na siebie odpowiedzialności jak dorośli. Dziewczyna oczekuje bowiem dziecka. Młodzi ludzie borykają się z problemami finansowymi, z biurokracją, z niechęcią najbliższego otoczenia. Ich miłość okazuje się jednak nadzwyczaj dojrzała. „Ciąża, jej rozwój i perypetie, jakie napotykają młodzi ludzie w związku z mającym narodzić się dzieckiem, stanowią ów «dramaturgiczny pierwiastek zawarty w rzeczywistości», o którym pisze Kieślowski”[18]. Kieślowski planował realizację kolejnego filmu w tej formule, który stanowiłby kontynuację Pierwszej miłości. Ewa, Ewunia (alternatywny tytuł Horoskop) miała opowiadać historię córki Jadzi i Romka. Autor książki o dokumentach Kieślowskiego Mikołaj Jazdon stawia tezę, że przyczyną rezygnacji z projektu były względy etyczne: „Sądzę, że Kieślowski zdał sobie sprawę, iż pełna i konsekwentna realizacja założeń wspomnianej tezy oznacza przekroczenie pewnych granic etycznych, których w jego głębokim przekonaniu dokumentalista nie ma prawa przekraczać" [19]. Obecność kamery w sposób znaczący zmieniała losy bohaterów, zbyt mocno ingerowała w porządek ich życia[20].

Dramaturgia dyptyku dokumentalnego Wojciecha Staronia
Do podobnej formuły kina dokumentalnego wraca współcześnie Wojciech Staroń. W moim przekonaniu w Syberyjskiej lekcji (1998) i Argentyńskiej lekcji (2011) realizuje zasadę „dramaturgii rzeczywistości”, dzięki czemu, choć struktura dramaturgiczna obu filmów przywodzi na myśl (szczególnie w przypadku drugiego filmu) kino fikcji, bliskie są one biegunowi „otwartości”. Sprzeczność pomiędzy porządkiem, wedle którego konstruuje się opowieść fikcjonalną, a „dramaturgią rzeczywistości” okaże się pozorna, jeśli założymy, że sama rzeczywistość nie jest chaosem, lecz drzemią w niej struktury, które w procesie po-
[17] K. Kieślowski, Film dokumentalny a rzeczywistość, praca dyplomowa napisana na Wydziale Reżyserii PWSFTviT w Łodzi w roku 1970, dostępna w Bibliotece PWSFTviT w Łodzi, sygn. D1035, s. 23. [18] M. Jazdon, Dokumenty Kieślowskiego, Poznań 2002, s. 43.

[19] Ibidem, s. 44.
[20] Warto pamiętać, że w PRL-u, w czasach gdy Kieślowski realizował Pierwsza miłość, towarzyszenie bohaterowi z kamerą miało zupełnie inne niż dziś znaczenie. W konsekwencji ofensywy propagandowej telewizji lat 7o. kamera stała się synonimem władzy i jej opresywności. 
znawczym odkrywamy i adaptujemy. Wówczas kino fikcji i kino faktów wyrastałyby z jednego pnia - pilnej obserwacji świata. Filmy Staronia powstawały, o czym warto pamiętać, w zupełnie innych warunkach niż utwór Kieślowskiego. Kamery są wszechobecne, a „relacje z życia” stały się pożywką telewizji i Internetu. Należy wskazać na jeszcze jedną istotną różnicę pomiędzy dokumentami Staronia a opowieścią Kieślowskiego. Ma ona bowiem konsekwencje dramaturgiczne i etyczne. Oba filmy reżysera wpisują się w coraz silniejszy we współczesnym polskim dokumencie nurt niefikcjonalnych utworów autobiograficznych. W pierwszym z nich Staroń filmuje swoją narzeczoną, a potem żonę, z którą wyjeżdża na rok w głąb Rosji, gdzie Małgosia ma uczyć języka polskiego. Choć zza kadru słyszymy głos autora i widzimy go przed kamerą w kluczowej scenie filmu, to główną bohaterką Syberyjskiej lekcji pozostaje jego żona. W drugim filmie autor ukrywa się za kamerą, a na bohatera tym razem wybiera swego 8-letniego syna. Zarówno Małgosia, jak i Jaś są oswojeni z obecnością kamery. Decyzja o wyjeździe i realizacji filmu stanowiła część ich życia, była kolejnym jego etapem. W wielu wywiadach dotyczących Argentyńskiej lekcji Staroń podkreśla, że powrót po latach do Ameryki Południowej, gdzie dekadę wcześniej realizował El Misionero (2000), był próbą zrobienia sobie "przerwy” w życiu, w codziennej gonitwie, i skupienia na sobie i rodzinnych relacjach. Filmowanie najbliższych sobie osób, uczynienie siebie i swej rodziny bohaterami filmu nie niweluje zupełnie moralnych dylematów związanych $\mathrm{z}$ realizacją tak intymnego dokumentu, z którymi borykał się Kieślowski, ale z pewnością je osłabia. W pierwszym filmie dyptyku autor ujawnia się kilkakrotnie, przede wszystkim w pierwszych słowach zza kadru: „Małgosia była moją dziewczyną. Pierwszy raz skierowałem na nią kamerę, gdy została nauczycielkąa". Po tych słowach Staroń oddaje głos bohaterce. Jego obecność będzie zaznaczana subtelniej: odbiciem w szybie, w monologu Małgorzaty robiącej dla niego sweter na drutach, w ujęciu ukazującym dłonie bohaterów i wreszcie - w scenie ślubu reżysera $\mathrm{z}$ Małgorzatą, kiedy jedyny raz podczas realizacji Staroń powierza kamerę komuś innemu. Sceny te i słowa pozwalają zachować widzowi świadomość istnienia osoby za kamerą, która współodczuwa świat z bohaterką, ale w żadnym momencie nie odbiera jej głównej roli. W zrealizowanej kilkanaście lat później Argentyńskiej lekcji reżyser niemal zupełnie ukrywa się za kamerą, a informacje o autobiograficznym charakterze filmu czerpiemy głównie bądź z rzeczywistości zewnątrzfilmowej[21], bądź z ramy fil$\mathrm{mu}-\mathrm{z}$ napisów końcowych. Staroń przekazuje widzowi doświadczenie zapośredniczone przez żonę i przez syna. Inaczej jednak niż w filmach nieautobiograficznych, gdzie owym ogniwem pośredniczącym obecnym w strukturze filmu jest wyłącznie bohater, tu mamy do czynienia z zapośredniczeniem podwójnym - poprzez bohatera i poprzez autora.

[21] Jaś pojawił się wcześniej jako bohater w filmie Wojciecha Staronia Na chwilę (2005). Na marginesie warto zaznaczyć, że film ten został zrealizowany podobną metodą jak Syberyjska lekcja i Argentyńska lekcja: długotrwałej, niemal rocznej obserwacji. 
W dyptyku Staronia podróż jest ponadto w obu przypadkach osią konstrukcyjną filmów. Jej motyw ma charakter wręcz archetypowy, a wyjazd i powrót pozwalają na zbudowanie klarownej ramy, w którą zamknięte zostają zdarzenia na Syberii i w Argentynie. W obu filmach pojawiają się sceny ukazujące drogę, docieranie do celu i sceny pożegnań przed powrotem do kraju. Zostały one jednak nieco inaczej rozmieszczone i sfunkcjonalizowane. $\mathrm{W}$ pierwszym $\mathrm{z}$ omawianych dokumentów ujęcia Małgorzaty podróżującej pociągiem na Syberię otwierają film. Towarzyszy im monolog bohaterki zza kadru: „Wojtek skończył szkołę filmową i chciał zacząć kręcić filmy. Postanowiliśmy, że wyjedziemy razem na Syberię. Ja miałam uczyć polskiego, a Wojtek chciał kręcić film. Do ostatniej chwili nie byliśmy pewni, czy zdecydujemy się naprawdę wyjechać na rok tak daleko". Wspomina, że postanowiła porzucić wszystkie swoje sprawy, by oderwać się, „porozmawiać ze sobą". Sekwencja otwierająca film jest stosunkowo długa, co pozwala ukazać warunki, w jakich odbywa się wyprawa, i zmieniający się stopniowo krajobraz i klimat. Dzięki monologowi widz poznaje ponadto motywacje bohaterki. W drugim dokumencie również znalazła się sekwencja przedstawiająca długą podróż: samolotem, autobusem i na koniec samochodem. Pełni ona funkcję ekspozycji, w której wyłącznie poprzez obserwację poznajemy bohatera. Choć autor filmu nie jest widoczny w żadnym ujęciu, to czujemy jego obecność manifestującą się poprzez sposób umieszczenia kamery. W ujęciach w samochodzie zarówno siedzący na tylnym siedzeniu Jaś, jak i podjazd do tymczasowego, argentyńskiego domu są filmowane z perspektywy siedzenia kierowcy. Specyficzne umieszczanie kamery stanie się wewnątrzfilmowym znakiem tożsamości reżysera oraz jego bliskiej relacji z bohaterem. Podróż w Argentyńskiej lekcji odbywa się w milczeniu. Ponadto sekwencję tę poprzedza tajemnicze, długie ujęcie umieszczone przed planszą z napisem tytułowym. Widzimy w nim w odległym planie dziewczynkę na drodze żegnającą się w strugach deszczu z jakimś mężczyzną. Jej sens będziemy zdolni odczytać znacznie później, gdy poznamy Marcię, argentyńską koleżankę Jasia, i jej ojca. Obie ekspozycje dostarczają nam więc informacji o bohaterach, choć mają one zupełnie inny charakter. W Syberyjskiej lekcji już drugie ujęcie wskazuje na bohaterkę, dziewczynę reżysera. Monolog pozwala zrozumieć jej wybory i poznać towarzyszące im uczucia. Przed napisami początkowymi pojawia się także plansza informująca o Polakach mieszkających na Syberii i wysyłanych tam nauczycielach języka polskiego, których zadaniem jest utrzymanie więzi pomiędzy potomkami zesłańców a ojczyzną ich dziadków. Ów napis ustawia do pewnego stopnia odbiór filmu. Zdaje się mówić: to nie tylko intymny portret Małgorzaty, ale również dokument socjologiczny o miejscu, do którego wyruszyła polonistka. W Argentyńskiej lekcji ilość umieszczonych w ekspozycji ujęć ukazujących twarz Jasia umożliwia nam zidentyfikowanie jego właśnie jako głównego bohatera. Dowiadujemy się również, że podróżuje z rodziną. W kilku kadrach widzimy mamę i młodszego brata. Emocje bohatera możemy odczytać 
jedynie z jego twarzy, ale pierwsze ujęcie na długo pozostanie zagadką. W Syberyjskiej lekcji widz otrzymuje znacznie więcej informacji już w pierwszej części filmu. Ekspozycja Argentyńskiej lekcji jest budowana na tajemnicy, na niedopowiedzeniu, które ma rozbudzić ciekawość odbiorcy.

W obu filmach czas akcji od momentu wyjazdu za granicę do pożegnania obejmuje rok. W obu wypadkach Małgorzata pracuje jako nauczycielka języka polskiego. Bieg zdarzeń do pewnego stopnia wyznaczają więc pory roku, które mają szczególne znaczenie w miejscach, gdzie ekstremalne warunki pogodowe (niezwykle mroźna zima na Syberii i ulewy w Argentynie) determinują życie mieszkańców. Zmieniająca się pogoda staje się zresztą tematem wielu ujęć i scen, szczególnie w Syberyjskiej lekcji, ponieważ na Syberii, jak stwierdza bohaterka, obowiązuje „rytm kartofla”. Deszcz staje się lejtmotywem Argentyńskiej lekcji. Reżyser wspominał:

Motyw wody powraca wielokrotnie. Fascynowała mnie ta woda w sensie plastycznym. Cała przyroda, tak inna niż u nas. Woda, rzeka, deszcz, ulewy, błoto, burze. Wydaje mi się, że przyroda potrafi wiele opowiedzieć o stanie bohatera. Oczywiście to romantyczne pojmowanie sztuki, ale w filmie to działa inaczej niż w literaturze, jest bardziej prawdziwe[22].

Deszcz jako motyw wizualny pojawia się jednak w obu filmach. Kompozycja filmu opartego na toposie podróży zostaje wzmocniona poprzez wykorzystanie deszczu jako elementu uspójniającego nie tylko na poziomie konstrukcji obu części dyptyku, ale również w warstwie semantycznej. W ekspozycjach staje się on znakiem oczyszczenia, ponownych narodzin. W chwili wyjazdu odsyła on do aktu odcięcia się od dotychczasowego życia i otwarcia na nowe, na sięganie do rezerwuaru „wszelkich potencjalności”. Staroń odsyła więc widza do dostrzeżonej przez Eliadego symbolicznej ambiwalencji wody[23].

Roczny wyjazd stanowi nie tylko o ramach czasowych omawianych filmów, ale przede wszystkim o ich dramaturgicznej konstrukcji. Christopher Vogler, wyjaśniając inspirujący wpływ mitologicznych rozważań Josepha Campbella na proces pisania scenariusza filmu fabularnego, zauważa:

Fabuły zbudowane według modelu Wyprawy Bohatera mają siłę oddziaływania, którą odczuć może każdy z nas, bo mają źródło w naszej wspólnej nieświadomości i odzwierciedlają powszechne, ogólnoludzkie problemy. [...] Historia bohatera, niezależnie od wszelkich jej możliwych wariantów, w swej istocie zawsze jest podróżą. Bohater porzuca swój wygodny, zwyczajny świat, by podjąć wyzwanie, ruszyć w nieznane[24].

Podróż jest archetypem, jak chcieliby strukturaliści - stałym wzorem opowiadania. Funkcją ekspozycji filmów Staronia jest więc zaznacze-

[22] W. Staroń, Argentyna bez tanga, rozm. B. Welbel, „FilmPro” 2010, nr 2, s. 32.

[23] M. Eliade, Sacrum - mit - historia, przeł. A. Tatarkiewicz, Warszawa 1970, s. 142-148.
[24] Ch. Vogler, Podróż autora. Struktury mityczne dla scenarzystów i pisarzy, przeł. K. Kosińska, Warszawa 2010, s. 5 i 7. 
nie momentu inicjującego wyprawę, który stanowi też początek opowiadania. To, co Vogler określa jako Wezwanie do podróży, zostaje w Syberyjskiej lekcji wyrażone w monologu Małgosi. Przekraczaniem kolejnych progów staje się zagłębianie w obcą społeczność. Bohaterka spotyka też Mentora w postaci ks. Ignacego i wreszcie wyrusza w drogę powrotną, następuje Odrodzenie[25]: „Chcę, żeby zawsze było nam tak dobrze w życiu jak tam, na Syberii”. Ten pobyt zmienił bohaterów, nauczył życia razem.

W pracy dyplomowej napisanej w łódzkiej Szkole Filmowej Staroń konstatuje: „Siła opowiadania nie wynika z pojedynczych ujęć i scen, ale z wzajemnych relacji między nimi”[26]. Opowieść zawarta w Syberyjskiej lekcji układa się w serię spotkań z ludźmi, którzy pozwalają bohaterce lepiej poznać początkowo obcą jej rzeczywistość. Pierwszym człowiekiem, który stał się jej naprawdę bliski, był przebywający od kilku lat na Syberii ks. Ignacy: „Ksiądz Ignacy był dla mnie przewodnikiem po tamtym świecie. Było mi o wiele spokojniej żyć z myślą, że on też tu jest i zawsze może pomóc”. Z nim Małgorzata wybiera się w podróż do Pichtińska, gdzie mieszka niewielka społeczność, wśród której zachowały się śpiewniki i modlitewniki polskie pisane gotykiem, on udziela ślubu Staroniom. Pozostali bohaterowie to dorośli uczniowie Małgorzaty. Wątek Walerego Cwietkowa - stróża, który sam nauczył się polskiego i zajmuje się tłumaczeniem Biblii z polskiego na rosyjski - powraca trzykrotnie; pana Aleksandra Kormanowskiego, lekarza - dwukrotnie. Spotkania z nimi pozwalają zobaczyć od środka Rosję, gdzie człowiek czuje się niepewnie, a w „duszy próżno”. Gdy przyjrzymy się układowi scen w Syberyjskiej lekcji, bez trudu można dostrzec, że w drugiej połowie filmu zwiększa się liczba spotkań Małgorzaty z mieszkańcami, a powracanie niektórych bohaterów zaświadcza o coraz większej trwałości relacji. Swoistym mostem łączącym te części filmu staje się scena wizyty w szpitalu psychiatrycznym usytuowanym na jednej z syberyjskich wysp. Ta scena o niezwykłym ładunku emocjonalnym otwiera bohaterkę na głębsze doświadczenie. Dojrzewanie bohatera to istotny element Campbellowskiego monomitu. W rozmowie z Billem Moyersem autor Bohatera o tysiacu twarzy stwierdza:

Campbell: Otóż głównym tematem wszystkich mitów jest taka bądź inna przemiana świadomości. Dotychczas myślałeś w pewien sposób, odtąd musisz myśleć w inny sposób.

Moyers: Jak dokonuje się przemiana świadomości?

Campbell: Przez próby albo przez objawienia niosące wiedzę. Próby i objawienia - oto w czym rzecz[27].

Przemianie świadomości towarzyszy ewolucja stanu emocjonalnego bohaterki analizowanego filmu od uczucia dojmującej tęsknoty, sa-

[25] Terminy te zostały zaczerpnięte ze schematu Christophera Voglera. Ibidem, s. 6.

[26] W. Staroń, Pojęcie „przemiany” na podstawie filmu „Syberyjska lekcja”, praca napisana na Wydziale
Operatorskim PWSFTviT w Łodzi, dostępna w Bibliotece PWSFTviT w Łodzi, sygn. D198, s. 16.

[27] Potega mitu. Rozmowy Billa Moyersa z Josephem Campbellem, przeł. I. Kania, Kraków 2007, s. 146. 
motności i smutku tuż po przyjeździe na Syberię, poprzez akceptację otoczenia i spokój, po ból rozstania, który jednak jest łagodzony przez poczucie sensu, jakie udało się bohaterce uzyskać. Zetknięcie z obcością pozwala jej lepiej zrozumieć siebie. Choć stopniowo integruje się z miejscową społecznością, to zachowuje świadomość własnej odrębności - przekonanie, że nigdy nie stanie się częścią tej rzeczywistości. W 24. spośród 36 scen filmu stwierdza: „Szczęściem jest taki spokój w środku, we mnie, i tutaj mam go w największej ilości jak do tej pory w życiu. Po prostu wielki spokój, który daje siłę". Równolegle dojrzewa związek bohaterki i autora. W niezwykle lirycznej scenie, portretującej codzienność Małgorzaty, robi ona sweter dla ukochanego. Zza kadru słyszymy wyznanie: „Jesteśmy ze sobą, a nie obok siebie. Nie wyobrażam sobie tego filmu o sobie. [...] Po prostu wyobrażam sobie film o nas. Film o mnie jest po prostu nieprawdziwy, bo ja sama nie istnieję sama teraz już". W scenie 34. zostaje ukazany ślub bohaterki i autora. Staje się ona momentem kulminacyjnym: najważniejsze znajomości zostały już zawarte, przyjaźnie utrwalone, spełnienie w związku odnalezione. Po niej następują jeszcze dwie sceny, które stanowią rozwiązanie akcji: koniec roku szkolnego i pożegnanie Małgorzaty oraz jej wyjazd. W eksplikacji filmu Staroń podsumowuje: „Wydarzenia splatają się w warkocz wątków, z których najważniejszy i spajający pozostałe staje się wątek dojrzewania Małgosi”[28].

Podróże miewają wiele wariantów, służą rozmaitym precyzyjnie określonym celom, te, z których rodzą się opowieści, zdają się jednak przebiegać wedle podobnych wzorów. Opisana wyżej opowieść w scenariuszu została jedynie zarysowana. Staroń nie wiedział bowiem, jak ułożą się relacje Małgorzaty z otoczeniem, kogo pozna, jacy będą jej uczniowie. Opierając się jednak na rzeczywistej bądź intuicyjnej wiedzy o archetypie podróży, mógł poczynić pewne założenia. Od początku pracy nad projektem wiedział, że dokument będzie „podwójnym portretem: bliskiej osoby oraz rzeczywistości, z którą przyjdzie jej się zmagać" [29]. Wiedział też, że będzie rejestrował codzienność dziewczyny oraz spotkania ze szczególnie interesującymi ludźmi, że postaci te muszą powracać w strukturze filmu kilkakrotnie „w celu zachowania ciągłości opisu" [30]. Zakładał formę pamiętnika i w jego obrębie chronologiczny porządek. Uwzględniał takie momenty jak „podróż, wprowadzenie się do nowego mieszkania, pierwsza lekcja, uroczystości szkolne, wyjątkowe spotkania lub podróże z ciekawymi ludźmi”. Część z tych założeń musiała być nieprecyzyjna i została wypełniona przez rzeczywistość, część pochodziła z kalendarza społeczności, w której znalazła się Małgorzata (np. Dzień Kobiet), część ostatnia to zdarzenia niezaplanowane, które były konsekwencją rozwoju wypadków i zmian bohaterki, w tym kluczowa scena ślubu. Pracując tą metodą, autor zawierzył rzeczywistości:

[28] W. Staroń, op. cit., s. 23.

[30] Ibidem, s. 28.

[29] Ibidem, s. 27. 
W żadnym wypadku nie należy odrzucać możliwości konstruowania filmowej opowieści zgodnie z rozwijającą się sytuacją. Życie samo pisze scenariusz. Jeśli będziemy dobrze wczytywać się w ten scenariusz i zaakceptujemy koleje losu takimi, jakimi są - to już dużo. [...] Największa trudność to ingerencja kamery w tę rzeczywistość i wybór takich jej fragmentów, które stworzą całość, zaczną współgrać ze sobą, zmierzając ku stworzeniu nowej wartości, możliwej tylko w filmie dokumentalnym. Otwartość na świat wynikająca z przemiany wewnętrznej, dokonanej pod wpływem wnikliwej obserwacji, jest warunkiem rozpoczęcia pracy[31].

Od początku istotą opowiadania Staroń uczynił konstytutywną według Voglera cechę scenariuszowej struktury - zmianę, przy czym kategorię tę odniósł do wewnętrznego życia bohaterki:

Skończony utwór powinien stać się wizerunkiem człowieka w trakcie przemiany. Wtedy film zaczyna emanować własnym życiem. Budzi się nowa, niezależna wartość, „Zwinięta” na rolce taśmy i zdolna oddziaływać z ekranu i zmieniać świat, ponieważ sama nosi w sobie ślad - kod przemiany[32].

Spoiwem filmowego opowiadania stało się skoncentrowanie scen według bloków tematycznych, ale przede wszystkim głos zza kadru, który nadał porządek dramaturgicznej strukturze, uzupełnił wiedzę o motywacjach zachowań. Co ciekawe, off Małgorzaty został napisany w większej części w czasie przeszłym. Autor nie ukrywa więc, że powstał on po realizacji, jest efektem refleksji dokonanej post factum. Choć komentarz dotyczy raczej emocji niż zdarzeń, jego forma w połączeniu z obrazem zbliża filmową narrację do pamiętnika, w którym zapisujemy wypadki i rozważania. Jest on jednak czymś zewnętrznym, dodanym do narracji budowanej za pomocą obrazów, nałożoną nań formą dyskursywną. Pełna emocji, ale i deskrypcyjna opowieść Małgorzaty niejako podąża za obrazem, wzmacniając konstrukcję wypływającą ze zderzenia z obcą jej rzeczywistością, której istotą stało się spotkanie z kolejnymi osobami, konfrontacja z obcymi zwyczajami.

W Argentyńskiej lekcji, drugiej części dyptyku, Staroń zrezygnował całkowicie $\mathrm{z}$ tego elementu. Wydaje się, że bardziej zawierzył „dramaturgii rzeczywistości”. Komentarz słowny został zastąpiony przez komentujące obrazy, które uobecniającą reżysera-autora i współbudują nastrój filmu. Są jednak przede wszystkim nośnikami znaczeń symbolicznych. Taką funkcję pełnią krótkie ujęcia (np. lejtmotyw mgieł unoszących się nad argentyńską selvą, gnijąca na drodze pomarańcza, żuk z trudem wspinający się na ścianę) lub całe sceny (np. kąpiel Marcii i Jasia w rwącym potoku tuż przed wyjazdem chłopca). Inaczej niż w Syberyjskiej lekcji, w filmie o Jasiu reżyser chętnie udziela głosu bohaterom. Słowo wypowiadane przez bohatera nabiera szczególnego charakteru. Jaś słabo zna hiszpański, jego przyjaciółka dopiero uczy się polskiego. Proces przyswajania języka i porządkowania rzeczywistości według językowych kategorii staje się niejako jednym z pobocznych wątków filmu. 
Także w Argentyńskiej lekcji spotkanie z Innym, z Obcym, zdaje się napędzać opowiadanie. Jaś nagle znajduje się w świecie, który jest diametralnie różny od tego, który znał. Staroń wspomina:

Rzeczywiście, początek miał trudny. Był obcy, inny, nie rozumiał języka i nie miał rozrywek, które w Polsce były w zasięgu ręki. Inaczej niż u nas, w Argentynie domy nie są budowane w skupieniu, ale rozrzucone w dużej odległości od siebie. Wokoło pola albo wręcz selva, czyli dżungla, i wielka rzeka graniczna z Brazylią w pobliżu. Ludzie żyją na tzw. cziakrach, czyli małych gospodarstwach. Centrum miasteczka to jedna ulica, jakiś urząd, szkoła, kilka domów wzdłuż drogi. Lekcje w szkole trwają tylko do 12 . Niewiele dzieci wychodzi na ulicę, by się razem bawić[33].

Jak w opowieści o Małgorzacie, tak i w filmie o Jasiu rozwój wypadków dawał się przewidzieć tylko do pewnego stopnia. Konflikt oparty na konfrontacji z nową rzeczywistością znalazł jednak nieoczekiwaną konkretyzację w postaci wątku Marcii. Dziewczynka zaczęła najpierw przychodzić na zajęcia z języka polskiego prowadzone przez Małgorzatę. Z czasem coraz częściej zaglądała do tymczasowego domu Staroniów. W końcu zaprzyjaźniła się z Jasiem. To dzięki niej i poprzez nią Jaś głębiej poznaje Argentynę. Przede wszystkim jednak dojrzewa pod wpływem Marcii, której sytuacja życiowa okazuje się niezwykle złożona. Dziewczynka ma pięcioro rodzeństwa. Dzieci mieszkają ze schorowaną matką i są na jej utrzymaniu. Marcia marzy, by zobaczyć ojca, który od dawna mieszka $z$ dala od ich domu i pracuje na plantacji. Ubóstwo, styl życia rodziny Marcii oraz konieczność brania odpowiedzialności przez dzieci za sprawy dorosłych były dla Jasia czymś zupełnie nowym, doświadczeniem, które pozwoliło mu dojrzeć. Ponownie więc proces przemiany bohatera pod wpływem przewodnika staje się osią konstrukcyjną zdarzeń. Wspiera go historia Marcii, którą można określić jako „wątek odnaleziony”. Przed laty Siegfried Kracauer pisał:

Terminem „wątek odnaleziony” określam każdą fabułę znalezioną w materiale autentycznej, materialnej rzeczywistości. Gdy dość długo patrzy się na powierzchnię jeziora lub rzeki, można odkryć na wodzie wzory i kręgi tworzące się wskutek wiatru lub wiru. Wątki znalezione są podobne do tych wzorów. Odkryte raczej niż wymyślone, są nierozłączne z filmami wyrażającymi intencje dokumentalne. Mogą więc zaspokoić tę potrzebę fabuły, która „pojawia się znowu w łonie filmu niefabularnego”[34].

Historia Marcii, jej rodziny, opowieść o wyprawie do ojca, w której odbyciu pomogli Staroniowie, wzmacnia wyrazistość dramaturgiczną historii Jasia. W przypadku Argentyńskiej lekcji żaden dodatkowy czynnik uspójniający, w postaci komentarza czy jakiejkolwiek innej bezpośredniej ingerencji autorskiej, nie jest potrzebny. Przyjaźń bohaterów i trudna miłość Marcii do rodziców to materiał pełen napięć i emocji. Splótł się z zaplanowaną strukturą dokumentu opartą na schemacie

[33] W. Staroń, Pokazać, czego nie widać, rozm. M. Piwowar, „Rzeczpospolita” 2011, nr 132 (8 czerwca 2010), s. A16.
[34] S. Kracauer, Teoria filmu. Wyzwolenie materialnej rzeczywistości, przeł. W. Wertenstein, Warszawa 1975, s. 266. 
wyjazdu w nieznane. Do pewnego stopnia w Argentyńskiej lekcji została zrealizowana struktura trzyaktowa. Momentem kulminacyjnym filmu jest bez wątpienia scena spotkania Marcii z ojcem. Następuje w finale sekwencji, którą można określić jako konfrontację. Później dochodzi już tylko do pożegnania i rozstania.

W jednym $\mathrm{z}$ wywiadów reżyser wyjaśniał:

Dla mnie robienie dokumentu to wejście na całkowicie nieznany obszar. Nie potrafię wymyślać wcześniej tematu i potem go wyłącznie odfotografować - przelać na zdjęcia zamierzenia z głowy czy gotowy już schemat. Jestem zawsze ciekawy, dokąd mnie film zaprowadzi i próbuję go zgłębiać w trakcie zdjęć i montażu. Często na koniec sam dziwię się efektom, kiedy powstaje dokument zupełnie odbiegający od początkowych założeń[35].

Założenia wstępne są więc w obu filmach ograniczone do niezbędnego minimum. W jednym wątki odnalezione w rzeczywistości potrzebują jednak elementu nadającego mu spójność, w drugim - nie. W obu mamy do czynienia ze strukturą zamkniętą. Ostateczny porządek filmów powstał rzecz jasna na stole montażowym, ale wypłynął z pilnej obserwacji świata.

Struktury dramaturgiczne w filmie dokumentalnym wpisują się więc w pewne continuum rozpostarte pomiędzy biegunami retorycznie uporządkowanego dyskursu i opowiadania o bohaterze lub bohaterach. Drugi z tych biegunów jest z pewnością bliższy metodzie realizacji, którą opisywał Łoziński jako otwarcie na rzeczywistość. Paradoksalnie w filmach wyrastających z rzeczywistości, bliskich jej dramaturgii, wykorzystywane są często rozwiązania, które identyfikujemy jako typowe dla fabuły. O ile można zatem zgodzić się z tezą Kieślowskiego o istnieniu „dramaturgii rzeczywistości”, to warto pamiętać, że każda forma opowiadania o niej jest nałożeniem na bieg zdarzeń konkretnej struktury. Pozwala ona na uporządkowanie rzeczywistości, ale wcale nie musi czynić jej fikcjonalną. Bez niej nie można byłoby jednak mówić o filmie. Czym zatem różniłby się film dokumentalny od fabularnego $\mathrm{w}$ aspekcie dramaturgicznego ukształtowania? Pytanie to dotyczy nie tylko konwencji, a więc estetyki, ale dotyka podstawowych kwestii ontologicznych i epistemologicznych, jeśli przyjmiemy, że opowiadanie jest formą poznawania. Paul Ricoeur oddziela stories - historie, które się opowiada, od history - historii, które buduje się na podstawie śladów dokumentalnych. Pierwsze byłyby bliższe kinu fikcji, drugie - filmowi dokumentalnemu. Opowiadania rządzą się odwiecznymi prawami, które drzemią w rzeczywistości w postaci prenarracji, a które stają się

[35] W. Staroń, Lubię robić film z przeróżnych „strzę-

pów”, rozm. D. Stopa, http://www.polishdocs.pl/pl/

czytelnia/821/ [dostęp 12.12.2014]. 
podstawą naszego widzenia zdarzeń, a tylko ostatnie szlify nadajemy im pod naporem tradycji, współczesnej nam kultury i mód.

Trudno oprzeć się wrażeniu - pisze Christopher Vogler - że Wyprawa Bohatera gdzieś realnie istnieje, jako wieczna rzeczywistość, platońska forma idealna, boski model. Na tym modelu wzorowane są nieskończenie liczne i mocno zróżnicowane kopie, z której każda odzwierciedla w pewien sposób ducha tej formy[36].

[36] Ch. Vogler, op. cit., s. XI-XII. O stałych i powtarzalnych wzorach opowiadania, które nie zależą od medium, pisali również: Joseph Campbell (Bohater o tysiacu twarzy, przeł. A. Jankowski, Kraków 2013), wielu badaczy mitów w kontekstach psychoanalitycznych, a wcześniej, innym językiem opisujący to zjawisko, strukturaliści. 